\title{
Exposure to particles and fungi in Portuguese swine production
}

\author{
S. Viegas, E. Carolino \& C. Viegas \\ ESTeSL - IPL, Lisbon, Portugal \\ R. Sabino \& C. Veríssimo \\ Mycology Laboratory - INSA, Lisbon, Portugal
}

\begin{abstract}
A number of studies have shown that exposure to airborne dust and microorganisms can cause respiratory diseases in humans. Agricultural workers, such as pig farmers, have been found to be at high risk of exposure to airborne particles. The aim of this study was to detect contamination caused by particles and fungi in 7 swine farms located in Lisbon district, Portugal. Environment evaluations were performed during the winter season of 2011 with a portable direct-reading equipment (Lighthouse, model 3016 IAQ) and it was possible to obtain data concerning contamination caused by particles with 5 different sizes (PM0.5; PM1; PM2.5; PM5; PM10). To assess air contamination caused by fungi, air samples of 50 liters were collected using a Millipore Air Tester (Millipore) by impaction method at a velocity of $140 \mathrm{~L} /$ minute and at one meter height, using malt extract agar supplemented with chloramphenicol $(0.5 \%)$. Air sampling was also performed outside premises, since this is the place regarded as reference. All the collected samples were incubated at 27 ${ }^{\circ} \mathrm{C}$ for 5 to 7 days. Results from particles' contamination showed that higher values were connected with PM5 and PM10 sizes and that smaller particles exhibit lower contamination values. Concerning the fungal load of the analyzed swine, the highest obtained value was $4100 \mathrm{CFU} / \mathrm{m}^{3}$ and the lowest was $120 \mathrm{CFU} / \mathrm{m}^{3}$. Forty six different fungal species were detected in the air, being Aspergillus versicolor the most frequent species found (20.9\%), followed by Scopulariopsis brevicaulis (17.0\%) and Penicillium sp. (14.1\%). Data gathered from this study corroborate the need of monitoring the contamination by particulate matter, fungi and their metabolites in Portuguese swine.
\end{abstract}

\section{INTRODUCTION}

Several studies have shown that human exposure to airborne dust and microorganisms, such as bacteria and fungi, can cause respiratory diseases. Agricultural workers have been found to be at high risk of exposure to airborne particles (Radon et al., 2003; Predicala and Maghirang, 2003; Baur et al., 2003; Rautiala et al., 2003; Dosman et al., 2005).

From a human health perspective, dust exposure in pig farming is the most important because of the large number of workers needed in pig production and the increasing number of working hours inside enclosed buildings (Iversen et al., 2000). In pig buildings, particulate matters like dust play a role in not only deteriorating indoor air quality but also in causing adverse health effects on workers (Donham et al., 1990; Pearson and Sharples, 1995; Mackiewicz, 1998; Kim et al., 2008). Generally, dust is recognized to adsorb and transport odorous compounds (Carpenter, 1986) and biological agents (Robertson et al., 1984; Kim et al., 2005) such as fungi (HSE, 2008). All these bioaerosoles in high concentrations together with fungal metabolites pose agricultural workers, and especially pig farmers, at increased risk of occupational respiratory diseases.

Animal confinement, such as pig farming, tends to increase the overall microbial load in the production environment caused by high amounts of feed and organic residuals (manure and wastewater) present in those environments. The number of animals and the handling and management required to work in these settings also contribute to enhance that microbial load (Clark et al., 1983; Cole et al., 2000; Douwes et al., 2003; Zejda et al., 1994). Exposure to bioaerosols in swines may vary depending upon the stage of the animals' growth, density, manure management procedures, used floor coverage, among others (HSE, 2009; Mc Donnell et al., 2008). Gathering temporal information about occupational exposure to particles and fungi is necessary to better understand eventual adverse health symptoms of workers.

The aim of this study was to determine contamination due to particles and fungi in 7 swine farms located in Lisbon district, Portugal. 


\section{MATERIALS AND METHODS}

Environment evaluations were performed during the winter season of 2011 with a portable directreading equipment (Lighthouse, model 3016 IAQ) and it was possible to obtain data concerning contamination caused by particles discriminated in 5 different sizes (PM0.5; PM1; PM2.5; PM5; PM10). This differentiation between particle size fractions is important because it allows the estimation of the penetration and deposition of dust within the respiratory system. Vincent and Mark (1981) demonstrated that the respirable dust is the fraction of airborne dust that reaches regions of the lung where the gas exchanges occur. It is composed with particles with less than $7 \mu \mathrm{m}$ aerodynamic diameter (size from PM0.5 to PM5).

Measurements were conducted in the vicinity of nasal area of the workers and during the performance of different tasks. In the swine farms, 3 to 11 measurements were undertaken and the mean value obtained for each particle size was the one considered. All measurements were done continuously and during $5 \mathrm{~min}$. In all the studied swine farms, workers did not use respiratory protection devices.

To assess air contamination caused by fungi, air samples of 50 liters were collected using a Millipore Air Tester (Millipore) by impaction method at a velocity of $140 \mathrm{~L} /$ minute and at one meter height, using malt extract agar supplemented with chloramphenicol $(0.5 \%)$. Air sampling was also performed outside premises, since this is the place regarded as reference. All the collected samples were incubated at $27^{\circ} \mathrm{C}$ for 5 to 7 days.

After laboratory processing and incubation of the collected samples, quantitative (colony forming units $/ \mathrm{m}^{3}-\mathrm{cfu} / \mathrm{m}^{3}$ ) and qualitative results were obtained, with identification of the isolated fungal species (Hoog et al. 2000).

To ascertain the existence of statistically significant differences between contamination results of different types of particles, it was used the Friedman test. Statistical analysis was performed with SPSS for Windows statistical statistical package, version 19.0.

\section{RESULTS}

\subsection{Particles}

Friedman's test showed the existence of statistically significant differences between the five sizes of particles $\left(\chi_{4}^{2}=228, p=0,000\right)$. The test for multiple comparisons revealed the existence of statistically significant differences between all particle sizes. In an exploratory data analysis, it appears that smaller particles exhibit lower contamination values.

The distribution of particles size showed the same tendency in all swine farms. Farms B and D, howev- er, presented higher levels of contamination, particularly in PM5 and PM10 (Table 1). These two farms were the ones having only natural ventilation as ventilation resource. The other swine farms have a combination between natural and mechanical (exhaust) ventilation.

Table 1. Particles measurements obtained in each swine farm (mean value/mg. $\mathrm{m}^{-3}$ )

\begin{tabular}{|c|c|c|c|c|c|c|}
\hline $\begin{array}{r}\text { Fa } \\
\text { rms }\end{array}$ & $\begin{array}{l}\quad \mathrm{N}^{\circ} \text { of } \\
\text { measure- } \\
\text { ments }\end{array}$ & $\begin{array}{l}\text { PM } \\
0.5\end{array}$ & $\begin{array}{l}\text { PM } \\
1.0\end{array}$ & $\begin{array}{l}\text { PM } \\
2.5\end{array}$ & $\begin{array}{l}\text { PM } \\
5.0\end{array}$ & $\begin{array}{r}\text { PM } \\
10.0\end{array}$ \\
\hline A & 11 & $\begin{array}{r}9.1 \mathrm{x} \\
10^{-4} \\
\end{array}$ & $\begin{array}{r}1.4 \mathrm{x} \\
10^{-3} \\
\end{array}$ & $\begin{array}{r}5.1 \mathrm{x} \\
10^{-3} \\
\end{array}$ & $\begin{array}{r}4.9 \\
\times 10^{-2} \\
\end{array}$ & 2.4 \\
\hline B & 7 & $\begin{array}{r}1.9 \mathrm{x} \\
10^{-3} \\
\end{array}$ & $\begin{array}{r}5.4 \mathrm{x} \\
10^{-3} \\
\end{array}$ & $\begin{array}{r}1.6 \mathrm{x} \\
10^{-2} \\
\end{array}$ & 1.1 & 4.9 \\
\hline $\mathrm{C}$ & 6 & $\begin{array}{l}2.5 x \\
10^{-4}\end{array}$ & $\begin{array}{r}7.4 \mathrm{x} \\
10^{-4}\end{array}$ & $\begin{array}{r}4.6 x \\
10^{-3}\end{array}$ & $\begin{array}{r}4.5 \mathrm{x} \\
10^{-2}\end{array}$ & 2.0 \\
\hline D & 5 & $\begin{array}{r}2.8 \mathrm{x} \\
10^{-4} \\
\end{array}$ & $\begin{array}{r}9.3 x \\
10^{-4} \\
\end{array}$ & $\begin{array}{r}8.8 \mathrm{x} \\
10^{-3} \\
\end{array}$ & 1.1 & 5.8 \\
\hline $\mathrm{E}$ & 3 & $\begin{array}{r}2.3 x \\
10^{-3} \\
\end{array}$ & $\begin{array}{r}4.3 \mathrm{x} \\
10^{-3} \\
\end{array}$ & $\begin{array}{r}1.2 \mathrm{x} \\
10^{-2} \\
\end{array}$ & $\begin{array}{r}6.0 \mathrm{x} \\
10^{-2} \\
\end{array}$ & 1.9 \\
\hline $\mathrm{F}$ & 7 & $\begin{array}{r}1.4 \mathrm{x} \\
10^{-4} \\
\end{array}$ & $\begin{array}{r}8.6 x \\
10^{-4} \\
\end{array}$ & $\begin{array}{r}7.6 x \\
10^{-3} \\
\end{array}$ & $\begin{array}{r}7.9 \mathrm{x} \\
10^{-2} \\
\end{array}$ & 3.5 \\
\hline $\mathrm{G}$ & 11 & $\begin{array}{l}3.9 \mathrm{x} \\
10^{-4}\end{array}$ & $\begin{array}{c}7.6 x \\
10^{-4}\end{array}$ & $\begin{array}{l}3.8 \mathrm{x} \\
10^{-3}\end{array}$ & $\begin{array}{l}4.5 x \\
10^{-2}\end{array}$ & 2.3 \\
\hline
\end{tabular}

\subsection{Fungi}

Concerning the fungal load of the analysed swines, the highest obtained value was $4100 \mathrm{CFU} / \mathrm{m}^{3}$ and the lowest was $120 \mathrm{CFU} / \mathrm{m}^{3}$. Forty six different fungal species were detected in air, being Aspergillus versicolor the most frequent species found (20.9\%), followed by Scopulariopsis brevicaulis (17.0\%) and Penicillium spp. (14.1\%) (Table 2).

Table 2. Fungal species most frequently found in the air from the analyzed swine farms

\begin{tabular}{|c|c|}
\hline Air & $\begin{array}{c}\text { Frequency } \\
\left(\mathbf{C F U} / \mathbf{m}^{\mathbf{3}}\right) \\
(\mathbf{N} ; \mathbf{\%})\end{array}$ \\
\hline Aspergillus versicolor & $3210 ; 20.9$ \\
Socpulariopsis brevicaulis & $2620 ; 17.0$ \\
Penicillium spp. & $2160 ; 14.1$ \\
Others & $7380 ; 48.0$ \\
\hline
\end{tabular}

\section{DISCUSSION}

The majority of the previous studies estimated particles' exposure by measuring the total mass concentration; very few studies on agricultural farms investigated the exposure regarding to particles' size. The size of the particles, however, affects their dep- 
osition in the respiratory system, resulting in different types of health effects (Lee et al., 2006). Our study gives information concerning 5 different sizes and this information permits the achievement of more detailed information concerning contamination with particles and their possible health effects.

Our data showed higher values in PM5 size and, predominantly in PM10, indicating that swine dust can penetrate into the gas exchange region of the lung (PM5) and may also produce disease by impacting in the upper and larger airways below the vocal cords (PM10) (Vincent and Mark, 1981).

Wathes and colleagues (1998) found that the inhalable dust emissions from pig buildings were $40 \%$ higher in the summer than in the winter, while respirable dust emissions were not affected greatly by the season. Considering this aspect, we can point out that there is a possibility that PM10 values can be even higher in the summer time.

In a European project developed in England, the Netherlands, Germany, and Denmark, stationary measurements in 256 animal buildings were performed and the mean value for inhalable dust in pig buildings was $2.19 \mathrm{mg} \cdot \mathrm{m}^{-3}$ (Seedorf, 1998; Takai, 1998, 1999; Iversen et al. 2000). In three of our seven studied farms (B, D and F) the obtained mean values were higher.

In a study developed by Donnell and colleagues (2008) in five Irish swine farms the same tendency was found on respect to the distribution of the particles' size, namely a median value of $2.99 \mathrm{mg} . \mathrm{m}^{-3}$ for inhalable and $0.19 \mathrm{mg} . \mathrm{m}^{-3}$ for respirable dust (Donnell et al., 2008).

The amount of dust in the air of livestock buildings is correlated to environmental factors such as ventilation, feeding practices, bedding materials, dung and slurry handling, and animal activity (Takai and Pedersen, 2000). A well designed and managed ventilation system will control the levels of gases, dusts and vapours, and it is an important factor in controlling odours from swine confinement buildings (Chastain, 2000). The absence of a ventilation system in B and D farms can contribute to explain the higher results obtained, particularly in PM5 and PM10.

Regarding the fungal load, different fungal counts were obtained when comparing with a study performed by Duchaine et al $\left(547 \mathrm{CFU} / \mathrm{m}^{3}-2862\right.$ $\mathrm{CFU} / \mathrm{m}^{3}$ versus $120 \mathrm{CFU} / \mathrm{m}^{3}-4100 \mathrm{CFU} / \mathrm{m}^{3}$ ). This difference maybe due to different procedures of building maintenance (Duchaine et al., 2010). In a study published by Jo and Kang (Jo \& Kang, 2005) Aspergillus spp. and Penicillium spp. were also the most frequent fungi found in swine.

Aspergillus versicolor, the most frequent species isolated, is known as being the major producer of the hepatotoxic and carcinogenic mycotoxin sterigmatocystin. The toxicity of this mycotoxin is manifested primarily in liver and kidney (Engelhart et al., 2002). Due to their easier detection, fungi are often used as an indirect indicator of mycotoxins presence both in agricultural and occupational settings. Because of that, we must consider the eventual exposure not only to fungal particles, but also to mycotoxins (Thrane et al., 2004). The mycotoxin sterigmatocystin is closely related to the mycotoxin aflatoxin, as a precursor of aflatoxin biosynthesis (Barnes et al., 1994) and it is classified by the International Agency for Research on Cancer as a class 2B carcinogen (i.e., as possibly carcinogenic to humans) (International Agency for Research on Cancer, 1987).

\section{CONCLUSIONS}

Data gathered from this study corroborate the need of monitoring the contamination by particulate matter, fungi and their metabolites in Portuguese swine. Results demonstrate high levels of particulate matter in the swine farms studied, particularly regarding PM5 and PM10 sizes. This study also raises the concern of occupational treat due not only to the detected fungal load, but also to the toxigenic potential of Aspergillus versicolor. In this setting, inhalation should be considered as a route of exposure to sterigmatocystin.

The evidence of respiratory disease in this occupational setting documented in many studies supports the need for the development of health protection programmes within the workplace.

\section{ACKNOWELEDGMENTS}

This study was funded by the Portuguese Authority for Working Conditions and would not have been possible without the assistance of the Portuguese Ministry of Agriculture, Portuguese Ministry of Health and swine farmers.

\section{REFERENCES}

Barnes, S., Dola, T., Bennett, J. \& Bhatnagar, D. 1994. Synthesis of sterigmatocystin on a chemically defined medium by species of Aspergillus and Chaetomium. Mycopathologia, 125,173-178

Baur, X., Preisser, A. \& Wegner R. 2003. Asthma due to grain dust. Pneumologie, 57, 335-339.

Carpenter, G.A. 1986. Dust in livestock buildings - review of some aspects. J Agric Eng Res, 33, 227241.

Clark, S., Rylander, R. \& Larsson, L. 1983. Airborne bacteria, endotoxin and fungi in dust in poultry and swine confinement buildings. Am. Ind. Hyg. Assoc. J., 44, 537-541. 
Chang, C., Chung, H., Huang, C. \& Su, H. 2001. Exposure of Workers to Airborne Microorganisms in Open-Air Swine Houses. Appl Environ Microbiol, 67(1), 155-161.

Chastain, J. 2000. Air Quality and Odor Control From Swine Production Facilities [Online] http://www.clemson.edu/extension/livestock/livestoc k/camm/camm_files/swine/sch9_03.pdf [24th September 2012].

Cole, D., Todd, L. \& Wing, S. 2000. Concentrated swine feeding operations and public health: a review of occupational and community health effects. Environ. Health Perspec., 108, 685-699.

Cormior, Y., Tremblay, G., Meriaux, A., Brochu, G. \& Lavoie, J. 1990. Airborne Microbial Content in Two Types of Swine Confinement Buildings in Quebec. Am Ind Hyg Assoc, 51(6), 304-309.

Donham, K. 2000. The concentration of swine production: effects on swine health, productivity, human health, and the environment. Toxicology, 16(3), 559-597.

Donham, K.J., Merchant, J.A., Lassie, D., Popendorf, W.J. \& Burmeister, LF. 1990. Preventing respiratory disease in swine confi nement workers: intervention through applied epidemiology, education and consultation. Am J Ind Med, 18, 241-261.

Donnell, P.E., Coggins, M.A., Hogan, V.J. \& Fleming, G.T. 2008. Exposure assessment of airborne contaminants in the indoor environment of Irish swine farms. Ann Agric Environ Med, 15, 323326.

Dosman, J.A., Lawson, J.A., Kirychuk, S.P., Cormier, Y., Biem, J. \& Koehnce, N. 2005. Occupational asthma in newly employed workers in intensive swine confinement facilities. Eur. Respir. J., 24, 698-702.

Douwes, J., Thorne, P., Pearce, N. \& Heederik, D. 2003. Bioaerosol health effects and exposure assessment: progress and prospects. Ann. Occup. Hyg., 47, 187-200.

Duchaine, C., Grimard, Y. \& Cormier, Y. 2000. Influence of Building Maintenance, Environmental Factors, and Seasons on Airborne Contaminants of Swine Confinement Buildings. AIHAJ - American Industrial Hygiene Association, 61, 1, 56 - 63.

Engelhart, S., Loock, A., Skutlarek, D., Sagunski, H., Lommel, A., Harald, F. \& Exner, M. 2002. Occurrence of Toxigenic Aspergillus versicolor Isolates and Sterigmatocystin in Carpet Dust from Damp Indoor Environments. Applied and Environmental Microbiology, 68 (8), 3886-3890.

Iversen, M., Kirychuk S., Drost, H. \& Jacobson, L. 2000. Human Health Effects of Dust Exposure in Animal Confinement Buildings. Journal of Agricultural Safety and Health, 6(4), 283-288.

Hoog, C., Guarro, J., Gené, G. \& Figueiras, M. 2000 Atlas of Clinical Fungi. (2th ed). Centraalbureau voor Schimmelcultures.
HSE. "Statement of evidence: Respiratory hazards of poultry dust Health and Safety" Executive 03/09 14 pages.

International Agency for Research on Cancer. 1987. Some naturally occurring substances. Monographs, vol. 10, Suppl. 7, p. 72. International Agency for Research on Cancer, Lyon, France.

Kogevinas, M., Anto, J., Sunyer, J., Tobias, A., Kromhout, H. \& Burney, P. 1999. Occupational asthma in Europe and other industrialized areas: a population based study. Lancet, 353, 1750-1754

Kim K., Ko H., Kim Y. \& Kim C. 2008. Assessment of Korean farmer's exposure level to dust in pig buildings. Ann Agric Environ Med, 15, 51-58.

Kim, K.Y., Ko, H.J., Lee, K.J., Park, J.B. \& Kim, C.N. 2005. Temporal and spatial distributions of aerial contaminants in an enclosed pig building in winter. Environ Res, 99, 150-157.

Lee, S., Adhikari, A., Grinshpun, S.A., McKay, R., Shukla, R. \& Reponen,T. 2006. Personal Exposure to Airborne Dust and Microorganisms in Agricultural Environments. Journal of Occupational and Environmental Hygiene, 3, 118-130.

Mc Donnell1,P., Coggins, M., Hogan, V. \& Fleming, G. 2008. Exposure assessment of airborne contaminants in the indoor environment of irish swine farms. Ann. Agric. Environ. Med., 15, 323326.

Mackiewicz, B. 1998. Study on exposure of pig farm workers to bioaerosols, immunologic reactivity and health effects. Ann Agric Environ Med, 5, 169175.

Novak, D. 1994. Prevalence and risk factors for airway diseases in farmers: a new EC multicentre project. Ann Agric Environ Med, 1, 81-82.

Oppliger, A., Charrie, N., Droz, P. \& Rinsoz, T. 2008. Exposure to Bioaerosols in Poultry Houses at Different Stages of Fattening; Use of Real-time PCR for Airborne Bacterial Quantification. Ann. Occup. Hyg., 52, 5, $405-412$.

Pearson, C.C. \& Sharples, T.J. 1995. Airborne dust concentrations in livestock buildings and the effect of feed. J Agric Eng Res, 60, 145-154.

Pedersen, S., Nonnenmann, M., Rautiainen, R., Demmers, T.G.M., Banhazi, T. \& Lyngbye, M. 2000. Dust in Pig Buildings. Journal of Agricultural Safety and Health. 6(4), 261-274.

Portengen, L., Preller, L., Tielen, M., Doekes, G. \& Heederik, D. 2005. Endotoxin exposure and atopic sensitization in adult pig farmers. J Allergy Clin Immunol, 115, 797-802.

Predicala, B.Z. \& Maghirang R.G. 2003. Field comparison of inhalable and total dust samplers for assessing airborne dust in swine confinement barns. Appl. Occup. Environ. Hyg.18, 694-701.

Radon, K., Danuser, B., Iversen, M., Jo“rres, R., Monso, E., Opravil, U. et al. 2001 Respiratory symptoms in European animal farmers. Eur. Respir. J., 17,747-754. 
Radon, K., Danuser, B., Iversen, M., Monso, E., Weber, C., Hartung, J., Donham, K., Palmgren, U. \& Nowak, D. 2002. Air Contaminants in Different European Farming Environments. Ann Agric Environ Med, 9, 41-48.

Radon, K., Garz, S., Riess, A. et al. 2003. Respiratory diseases in European farmers-II. Part of the European Farmers' Project. Pneumologie, 57, 510517.

Rautiala, S.J., Kangas, K., Louhelainen \& Reiman, M. 2003. Farmers' exposure to airborne microorganisms in composting swine confinement buildings. Am. Ind. Hyg. Assoc. J. 64, 673-677.

Rimac, D., Macan, J., Varnai, V., Vuc`emilo, M., Matkovic', K., Prester, L., Orct, T., Tros`ic',I. \& Pavic ic, I. 2010. Exposure to poultry dust and health effects in poultry workers: impact of mould and mite allergens. Int Arch Occup Environ Health, $83,9-19$.

Robertson, J.H. \& Frieben, W.R. 1984. Microbial validation of ven filters. Biotechnol Bioeng, 26, 828835.

Senthilselvan, A., Dosman, J., Kirychuk, S., Barber, E., Rhodes, C., Zhang, Y. et al. 1997. Accelerated lung function decline in swine confinement workers. Chest, 111, 1733-1741.

Simpson, J., Mc Niven, R., Pickering, C., Oldham, L., Fletcher, A. \& Francis, H. 1999 Comparative Personal Exposures to Organic Dusts and Endotoxin. Ann Occup Hyg 1999, 32(1), 107-115.

Takai, H. \& Pederson, S. 2000. A Comparison Study of Different Dust Control Methods in Pig Buildings. App. Eng. in Agri., 16(3), 269-277.

Thrane, U., Adler, A., Clasen, P., E., Galvano, F., Langseth, W., Lew, H., Logrieco, A., Nielsen, K.,F. \& Ritieni, A. 2004. Diversity in metabolite production by Fusarium langsethiae, Fusarium poae, and Fusarium sporotrichioides. Int. J. Food Microbiol, 95,257-266.

Zejda, J.E., Barber, E.M., Dosman, J.A., Olenchock, S.A., McDuffie, H.H., Rhodes, C.S. \& Hurst, T.S. 1994. Respiratory health status in swine producers relates to endotoxin exposure in the presence of low dust levels. J. Occup. Med., 36, 49-56.

Wan-Kuen, J. \& Jung-Hwan, K. 2005. Exposure Levels of Airborne Bacteria and Fungi in Korean Swine and Poultry Sheds. Archives of Environmental \& Occupational Health, 60, $\underline{3}, 140-146$.

Wathes, C., Phillips, V., Holden, M., Sneath, R., Short, J., White, R., Hartung, J., Seedorf, J., Schro, M., Linkert, K., Pederson, S., Takai, H., Johnsem, O., G root, K.,Uenk, G., Metz. J., Hinz, T., Caspary, V. and Linke, S. 1998. Emissions of Aerial Pollutants in Livestock Buildings in Northern Europe: Overview of a Multinational Project. J. Agri. Eng. Research, 70, 3-9. 